\title{
Social Empowerment of Remote Indigenous Peoples: Study of Village Housing Program in Sula District North Maluku, Indonesia
}

\author{
Abdulhalil Hi Ibrahim ${ }^{1,}$, , Muhlis Hafel ${ }^{2}$, Saiful Deni ${ }^{1}$, Syaiful Madjid ${ }^{1}$, Saman Fokaaya ${ }^{3}$ \\ ${ }^{1}$ Department of Government Science, Universities Muhammadiyah Maluku Utara, Ternate, Indonesia \\ ${ }^{2}$ Department of Political Science, Universities Muhammadiyah Maluku Utara, Ternate, Indonesia \\ ${ }^{3}$ Department of Administration Science, Universities Muhammadiyah Maluku Utara, Ternate, Indonesia
}

Email address:

halilibrahim@ummu.ac.id (A. Hi Ibrahim)

*Corresponding author

\section{To cite this article:}

Abdulhalil Hi Ibrahim, Muhlis Hafel, Saiful Deni, Syaiful Madjid, Saman Fokaaya. Social Empowerment of Remote Indigenous Peoples: Study of Village Housing Program in Sula District North Maluku, Indonesia. Journal of Public Policy and Administration.

Vol. 4, No. 4, 2020, pp. 61-70. doi: 10.11648/j.jppa.20200404.11

Received: September 24, 2020; Accepted: October 14, 2020; Published: October 21, 2020

\begin{abstract}
In this paper, social empowerment programs for remote indigenous peoples (KAT) evaluated to ensure that the program has run according to established rules or needs improvement and strengthening. This study uses qualitative methods, and the location chosen as the object is Sula District North Maluku, Indonesia. This study was conducted in the KAT Village location: Pancoran Kum Hamlet, North Mangoli District. The result showed that the social empowerment program implementation for remote indigenous communities in the Kadai tribe community in Pancoran Kum Hamlet, Waisakai Village, North Mangoli sub-district, has been going well. According to the determined mechanism, it is seen from the community's positive response when receiving a remote customary community housing program that has been completed. The social service incorporation and village community empowerment is an inhibiting factor in social empowerment programs implementation for small indigenous communities in Pancoram Kum Hamlet. Also, limited funds are an inhibiting factor social empowerment programs implementation, where every year is only IDR 350 Million budgeted in the social sector, one of which is in KAT midwives. Therefore, an increase in the funding portion of both central and regional governments need to maximize the implementation program. The Provincial Government needs to build cooperation with the regency/city government to follow up on the Central Government empowerment program after the community has been successfully relocated or organized in one settlement.
\end{abstract}

Keywords: Social Empowerment, Remote Indigenous People, People Welfare, Poverty Alleviation

\section{Introduction}

Community empowerment is a process whereby communities, especially those who are resource-poor, women, and other neglected groups, are supported to improve welfare [1] independently. Meanwhile, efforts to empower people must do in three ways: creating an atmosphere that allows the community's potential to develop. Second, strengthening the potential possessed by the people by implementing concrete steps. Third, protect and defend the interests of vulnerable communities [2-4]. Empowerment of remote indigenous communities is a strategic choice to tackle poverty. In this connection, the government has issued a policy through the Minister of Social Affairs Regulation No. 09/2012 concerning remote indigenous communities' empowerment. It is the right step so that there is no widening gap. Philosophically, the remote indigenous community empowerment program policy is one of the programs carried out by the government to improve citizen social welfare in remote areas.

Remote indigenous communities are also one of the persons with social welfare problems in Indonesia. Indonesia Regulation No. 8/2012 concerning people with social welfare problems (PMKS) are individuals, families, groups, or communities who cannot carry out their social functions due 
to an obstacle, difficulty, or disturbance. Their physical needs cannot be fulfilled physically, spiritually, socially, and adequately [5]. The welfare of Indigenous Peoples has become a severe concern of Indonesia's development, reflected in the fact that indigenous peoples have become a development priority outlined in the National Medium-Term Development Plan (RPJMN). The Government of Indonesia has a firm legal basis for realizing the social protection of indigenous communities. It affirms that the customary law community's unity and legal rights are recognized and respected by the state. Article 18 B paragraph (2) of the 1945 Constitution cited above guarantees all indigenous peoples in Indonesia.

Meanwhile, as mentioned in Article 28, paragraph (3) of the 1945 Constitution, traditional communities' cultural identity and rights are respected in harmony with time and civilization's development. These statements are an official decree, which shows that none of the indigenous people's groups have been forgotten or left behind in the development process. In this regard, Indonesia is bound by international commitments regarding the recognition of indigenous people's rights. On September 13, 2007, the Indonesia Government signed the United Nations Declaration on The Rights of Indigenous Peoples (UNDRIP), which mandates that Indigenous Peoples have the same rights regarding livelihoods, education, maintaining identity, and free from all forms of discrimination. [6].

To carry out this empowerment program, of course, the central government needs support related to the remote indigenous community empowerment program (KAT) by providing the national budget (APBN) under Law Number: 17/2006 concerning State Finances. The provision of APBN funds through de-concentration is intended as the central government's attention manifestation to the regional government's performance for KAT empowerment. The budget allocation is based on a priority scale based on target achieved, population size, funding allocation, and local support. As a continuation of ongoing activities of remote indigenous community empowerment in Indonesia, President Joko Widodo on December 23, 2014, signed the Presidential Regulation No. 186/2014 concerning social empowerment of remote indigenous communities and then strengthened by the Republic of Indonesia Social Ministerial Regulation No. $12 / 2015$ concerning implementation presidential regulation No. 186/2014 concerning social empowerment of remote indigenous communities. Article 1, paragraph 1 of the Presidential Regulation, states that Social Empowerment is all efforts directed at making citizens experiencing social problems have the power to fulfill their basic needs. The empowerment of Remote Indigenous Communities (KAT) aims to realize; a) Protection of rights as citizens; b) Meeting basic needs; c) KAT integrity with the more comprehensive social system; and D. Independence as a citizen. The Indonesian Ministry of Finance in 2014 restructured each ministry/institution, so the KAT empowerment program/activity experienced an excellent structure/activity which was financed through de-concentration funds and assistance tasks. Previously, KAT empowerment was a priority sector program in the weak empowerment program group and KAT with other social problems.

The Presidential Regulation also emphasizes that the Social Empowerment of KAT is intended to develop KAT's independence to fulfill its basic needs. Furthermore, the social empowerment of remote indigenous communities is carried out based on KAT criteria. KAT criteria, as referred to, include; 1. Limited access to essential social services; 2. Closed, homogeneous, and their livelihood depends on natural resources; 3. Marginal in rural and urban areas; and 4. Live in border areas between countries, coastal regions, outermost islands, and the remote regions. Besides, social empowerment of remote indigenous communities also carried out in the fields of a) Settlement; b) Population Administration; c) Religious life; d) Health; e) Education; f) Food security; g) Provision of access to employment opportunities; h) Provision of land access; i) Social advocacy; j) Social services, and k) Living environment. The remote indigenous community is poverty. When compared with Indonesian citizens in general, their living conditions and livelihoods are relatively left behind. They generally reside in the mountainous, inland, sea, small islands, and border areas between countries and the industrial regions.

Based on the Directorate of Remote Indigenous Community Empowerment (2013) data, Indonesia's KAT population is still relatively large. There are 213,080 households in 24 provinces with 263 districts and 1,044 sub-districts in 2,304 villages, and 2,971 locations. Meanwhile, based on the year (2014), the number of remote indigenous communities spread across 24 provinces, 207 districts, 801 sub-districts, 1,758 villages, and 2,019 locations 23,166 households. Until now, as many as 97,011 families have been empowered, while there are not yet recorded as many as 130,031 families. Also, 4,124 homes were being assigned during the year (2015). The realization of KAT empowerment in North Maluku Province until the end of 2016 is as follows: 1,495 households have been empowered, 626 families are being empowered, and 10,612 homes have not yet been assigned. There are some problems relating to isolated/remote tribes in North Maluku Province, among others; The Tugutil tribe inhabiting the mountains/hills of Halmahera, the Mange tribe in Taliabu, and the Kadai tribe in the Sula Islands. The Kadai tribe in the Sula Islands Regency inhabits several points on the island of Mangoli, some of them in the Pancoran Kum Hamlet and the Wai Nanas Village in the North Mangoli District. While in Auponhia Village is located in South Mangoli District and Leko Kadai Village, West Mangoli District.

Based on the phenomenon that occurs, it can be said that various social empowerment implementations of KAT from the government have not run optimally. The condition is seen from many KAT conditions not changed from time to time, where after receiving KAT housing construction assistance, there is no sustainability of empowerment implementation. Such as diagnosis and providing motivation, skills training, mentoring, providing capital stimulants, business equipment, 
and business premises, increasing access to marketing business results, supervision and social advocacy, strengthening social harmony, structuring the social environment, and further guidance mandated by Presidential Regulation 186/2014.

Several programs to protect and advance indigenous peoples' lives by the government are settlements provision, population administration, religious life, agriculture, health, and education. However, indigenous people's empowerment generally not sustainable, and support across sectors is almost non-existent. The study on indigenous people's empowerment and grant contributions is also minimal. As a result, various development target gaps such as poverty, MDGs, and food security are found in indigenous peoples' territories.

With this background, this study of the social empowerment of remote indigenous communities was carried out. Social empowerment of remote indigenous communities is one of the programs aimed at empowering and improving indigenous peoples' welfare. Considering that remote indigenous communities are part of indigenous peoples, this study aims to identify remote indigenous people's problems and accelerate regional development targets achievement. The various phenomena previously described are exciting to conduct in-depth analysis to determine the implementation of Presidential Regulation No. 186/2014 concerning the social empowerment of remote indigenous communities in the Sula District.

\section{Literature Review}

\subsection{Concepts of Policy}

According to Sri Soemantri, a policy is a concept, and principle becomes a plan outline and basis for implementing a leadership job and way of acting [7]. On the other hand, Klein explained that policy is an act of conscious and systematic use of suitable means, with clear political objectives as targets carried out step by step [8]. In comparison, Kuypers explained that the policy is an arrangement of; the goals chosen by public administrators both for self-interest and for the benefit of the group, the roads, and means chosen by him, the moments they choose [9]. The policy is essentially a position that, once stated, will affect decision success made in the future. The policy definition is an instant decision or action looking at the urgency and situation/conditions encountered in regulations written or oral decisions based on discretionary authority.

According to Robert R. Mayer and Ernest Greenwood, defining policy can be formulated as a decision that outlines the most effective and most efficient way to achieve a goal that is set collectively [10]. The system is a plan or program about what will be done in a particular problem face and how to do something been planned or programmed [11]. The policy is generally used to indicate the most critical choices in both organizational or private life. The procedure is free from the word political connotation, which is often believed to contain the meaning of partiality and corruption [12]. According to
Tomas Dye, the policy is whatever the government chooses to do or not to do [13]. The policy definition from Thomas Dye implies that (1) the system was made by a government agency, not a private organization, (2) the policy concerns choices that must be made or not made by a government agency.

Furthermore, according to Dye, if the government chooses to do something, of course, there is a purpose because public policy is the government's action. If the government decides not to do something, it is also a public policy with a goal. In their perspective, Heinz Eulau and Kenneth Prewitt define public policy as a permanent decision characterized by consistency and repetition of behavior from those who make and from those who comply with the decision [14]. Carl Friedrich offered another definition of the policy. He said that the system is a series of actions/activities proposed by a person, group, or government in a particular environment where there are obstacles (difficulties) and possibilities (opportunities). The policy is proposed to be useful in overcoming it and achieving the intended purpose [15]. James Anderson et al. provides an understanding of the definition of public policy as a series of activities that have a specific purpose that is followed and carried out by an actor or group relating to a concerning issue [16].

Public policy is a political decision developed by government bodies and officials. Therefore, a unique characteristic of public policy is that political decisions are formulated by what David Easton calls authority in the political system, namely: senior, supreme head, executive, legislative, judges, administrators, advisors, kings, and so. Easton said that those who are authorized in the political system to formulate public policy are involved in the political system's daily affairs and have responsibility for a particular problem, which at one point they are [17]. Furthermore, Bridgemen and Davis (2004) explained that public policy has at least three interlinked dimensions, namely as an objective (objective), as a choice of legal and legal actions (authoritative choice), and as a hypothesis [18]. From the definition above, the authors believe that the Policy is a series of political decisions proposed by groups or political elites responsible for a particular problem. Public policy is intended for the common good.

\subsection{Concepts of Implementation}

Implementation is a stage carried out after the rule of law is established through a political process. The sentence seems to indicate performance is more meaningful non-political, that is, administration. More broadly, implementation-defined as the administrative law process involves various actors, organizations, procedures, and techniques carried out so that the policies that have been set effect policy objectives achievement. Implementation Study is how change occurs, how to change the possibility raised. Implementation is also a microstructure study of political life: how organizations outside and within the political system carry out their affairs in interacting with each other [19]. However, the implementation study is also policy studies that lead to implementing a policy process [20]. 
Meanwhile, some various variables or factors affected policy implementation; First, George C. Edwards III theory [21] consists of communication, resources, disposition, and Bureaucratic structure. Second, Van Matter and Van Horn's approach [22] consists of policy size and objectives, resources, characteristics of implementing agencies, disposition, communication between organizations, and implementing activities, economic, social, and political environment. Third, Daniel Mazmanian dan Paul Sabatier's theory [23], consists of natural or whether it will address the problem. The policy ability to structure the implementation process appropriately, and variables outside the law that affect implementation; d) Merilee S. Grindle theory, consists of content of the policy and policy context.

\subsection{Concepts of Social Empowerment}

Empowerment is a process of people to become strong enough to participate in, control over, and influence the events and institutions that affect their lives. Empowerment emphasizes that people acquire sufficient skills, knowledge, and power to influence their lives and the lives of other people they care about [24]. The essence of empowerment is centered on humans and humanity; in other words, humans and society as normative, structural, and substantial benchmarks. Meanwhile, empowerment can be interpreted as a process towards the culture or providing power/ability from those who have power to those who have little or no control. Understanding the circle shows the series of actions or steps taken in a systematic chronological order reflecting the efforts to change the less empowered people towards empowerment. The process will refer to an actual activity carried out in stages to change a weak community's condition, knowledge, attitude, and practice towards the mastery of knowledge, conscious attitudes, and excellent skills. Empowerment should pass several stages: first, helping the community in finding the problem. Second, analyze the situation independently. This activity is usually carried out by brainstorming, forming discussion groups, and holding meetings with the community periodically. Third, determine the problem's priority scale, in the sense of sorting and selecting each of the most pressing issues to be solved. Fourth, look for ways to solve the problems being faced, among others, by socio-cultural approaches that exist in society. Fifth, implement concrete actions to resolve the issue at hand. Sixth, evaluate the whole set and process of empowerment to assess the extent of its successes and failures.

Therefore, empowerment is a process and a goal. As a process, empowerment is a series of activities to strengthen vulnerable groups' power or empowerment, including individuals who experience poverty problems. As a goal, empowerment refers to the circumstances or results achieved by a social change: people who are empowered, have power or have knowledge and abilities to meet their physical, economic, and social needs.

\subsection{Public Participation}

Participation as feed-forward and feedback information [25] is defined as the community's role where a continuous two-way process takes place to increase the community's full understanding of an activation process, where environmental problems and needs are being analyzed by a body [26]. Based on its nature, community participation can be divided into two, namely, consultative involvement and participation that is a partnership [27, 28]. Consultative participation occurs when between decision-making officials and community groups concerned, community members who have the right to be heard and told, where the final decision remains in the hands of decision-making officials. Whereas in the context of participatory participation, decision-making officials and community members are partners who are relatively equal in position. They discuss problems together, look for alternative solutions to problems, and discuss decisions. According to Cohen and Uphoff, participation consists of four activities: making decisions, implementing, obtaining results (benefits), and evaluating all activities [29].

\subsection{Concept of Remote Indigenous Communities}

During this debate over indigenous peoples' terms and definitions, various terms are used in the laws and regulations. Some names refer the same or almost the same-starting from the term indigenous peoples, customary law communities, traditional communities, remote ordinary communities, to the term indigenous village or other names. Based on various terms available, the law term is widely used is the customary law community. The term used as a form of grouping community category called the legal community (rechtsgemeenchappen) is a community whose entire community is bound as a single entity based on the law used is the law custom. The term translation of rechtsgameenchappen is popularized by indigenous legal thinkers such as Van Vholenhoven [30] and Teer Haar [31].

Since the late $1990 \mathrm{~s}$, attention to indigenous peoples has begun to burst, especially for remote indigenous communities (KAT) in Indonesia. These concerns include: first, changing terms or negative mentionings such as isolated communities, backward communities, becoming remote communities, or remote indigenous communities. According to Presidential Decree No. 111 of 1999 and Kepmensos No. 06 / PEGHUK / 2002, remote indigenous communities (KAT) are social and cultural groups that are local and scattered and have little or no involvement in social, economic, and political networks and services. Second, there is recognition from the government of isolated indigenous people existence, recognition of the social and economic rights of remote indigenous communities, recognition of the protection of traditions and customs of remote indigenous communities, and recognition of the empowerment of remote indigenous communities. Formal definition, as stated in Presidential Decree No. 111/1999, is the umbrella that forms the legal basis for the remote traditional community empowerment (KAT) program. In contrast, the operational definition is arranged to outline the formal definition in more detail to be applied following the criteria and characteristics of remote indigenous communities (KAT) in each region. 


\section{Study Methods}

The present study uses a qualitative descriptive study to describe the nature of a temporarily running state when the study is conducted and examine the causes of a particular symptom. The study was conducted to provide a more detailed picture of a sign or phenomenon. This study's final results are usually in typologies or patterns regarding the phenomena under discussion.

The location chosen as the object of this study is DSPMD Sula Islands Regency. In addition to the SPM Islands Regency DSPMD, this research was conducted in the KAT Village location: Pancoran Kum Hamlet, North Mangoli District. The study was carried out of Remote Indigenous Communities in the Pancoran Kum Hamlet. Social Empowerment of Remote Indigenous Communities is one of the programs aimed at empowering and improving indigenous peoples' welfare. So far, empowerment programs have not touched the area. Considering that remote indigenous communities are part of indigenous peoples, this study aims to identify the problems and needs of small indigenous communities in particular and indigenous peoples in general in accelerating regional development targets' achievement.

Data sources literature and actions (interviews), the rest is additional data such as documents and others. For this reason, data retrieval is divided into 2 (two) types of primary and secondary data. To Obtain data and information following the problem to be studied, the writer will use several data collection techniques, including observation, interview, and documentation. In addition to using some of the data collection techniques, obtaining better, more complete, and in-depth data pursued by applying participatory methods. Participatory methods are data collection methods carried out in a way, data collectors stay together (even doing joint activities) with prospective respondents for some before data collection is done. Through this method, besides the respondent will provide complete and honest information without prejudice, data collectors (based on experience and observations that have been made) can filter in advance the truth of the information conveyed in response.

According to Miles and Huberman [32] that the analysis consists of three activities that coincide: data reduction, data presentation, and concluding/verification. Data analysis uses three steps of data reduction, data presentation, and conclusion. The data validity was carried out to prove whether the study is scientific and test the data obtained. Data validity test in qualitative research includes test, credibility, transferability, dependability, and confirmability.

\section{Result and Discussion}

\subsection{Pancoran Kum Hamlet and Remote Indigenous Community Housing Program (KAT)}

Pancoran Kum is a hamlet that lives far from the crowd and can be said to be a remote area. The majority of the Pancoran Kum community work as farmers, whose income is uncertain depending on natural conditions. We can know the activities in agriculture itself, and it seems that farmers and their families do not have to be always on the farm. In specific periods, especially after the coconut/copra harvest stage is over, they have much free time because, at such times, they usually only go to their agricultural breaks. Thus, they can be used to do other work, such as fishing (fishing) as additional or side livelihoods. It is done to reduce the burden on the family, which is increasingly increasing day by day. Their homes are woven bamboo (au lil; Sanana language) and roofed with sago leaves (sa'a hosa). However, in 2015, through the Social Service of Sula district, Pancoran Kum received KAT housing assistance of 35 houses to be occupied. The person responsible for this housing program was Mr. Rivai Masuku (Head of KATDSPMD). From the interview results, Mr. Rivai Masuku related to the existence of the KAT housing program. Here are the interview results: The presence of this program is beneficial for people who are far from the community and the government's reach. We are aware of the Kadai tribe's existence in Pancoran Kum Hamlet from a community report that says there is a tribe that is marginalized. Since then, we have verified the location and determined the village to get KAT housing assistance. Initially, their houses/houses were made of woven bamboo with sago leaves; some were hanging houses (Uma Leb). (Interview: May 5, 2018. 12.00).

The KAT location in Pancoran Kum is based on remoteness in terms of geography, socio-economic backwardness, and cultural and political alienation. Geographically, the Pancoran Kum Village is remote because it is far from the district government center and far from necessary social service facilities. The condition is also compounded by the difficult, far, and far transportation access conditions that have to go by sea to get to the KAT location. If this location cannot reach the east/wave season, the interview results show that the regional government, in this case, the Social Service is very responsive to public information. The existence of this program is beneficial to remote communities far from the reach of the people. This program is also helpful for people who initially did not have a place to live; some tribal Kadai lives in hanging houses/garden houses in the forest. Now they have a place to live on the coast. Such activities, such as KAT housing, are expected to help KAT residents adapt to all aspects of development as a whole. Besides trying to create conditions so that KAT residents can absorb new values that emerge with the government development program. It can be known from an interview with Mr. Martono Upara (Chairman of $R W 3$ Pancoran Kum). Here are the interview results: We used to live in the garden house after occupying this area. However, after this assistance, we also have a home on the coast to be settled ". (interview: April 21, 2018. At 11.24).

The housing program for remote indigenous communities (KAT) can help people who do not have a house now can have it. Nevertheless, after getting KAT housing assistance from the Sula islands district local government, there has been no other program from the provincial government to coach and empower them as required. They were mandated by Presidential Regulation No. 186/2014 concerning the social empowerment of remote indigenous communities and 
Regulation of the social minister of the Republic of Indonesia No. 12/2015 concerning the implementation of presidential regulation number 186 of 2014 concerning social empowerment of remote indigenous communities.

It is known from interviews with the Head of Pancoran Kum Hamlet. The following are excerpts of an interview with Mr. Vitalis Landa: First, the government wants to build this house and accept it well. We are happy that the government is biking, but he has a place. However, since the housing was finished and occupied from the first house, there was no government attention. In contrast, before they (the local government) established this housing estate, they promised us that we would be fostered for 3 (three) years, but we have only been left until now. (interview: April 21, 2018. At 10:00).

The programs implemented by the government have been good. However, they have not trained and educated the community to develop because the government often targets only physical housing construction or community housing. After the program finished, no other programs were implemented by the government to improve people's lives in the future. Such as providing formal or informal education, agricultural counseling, and skill improvement that citizens already own to enhance the community's economy and welfare. The same thing was conveyed by one of the residents of Pancoran Kum Hamlet, Mr. Karolus Nggua (40 years old): From the beginning, they came here to make this KAT housing, and the people here accept it well. Who does not want someone to make a house? Yesterday they said in the people (Us) that if they were finished for this house, there would be another formation in 1-3 years. After completing the house and handing over the keys, there has been no coaching from them. (Interview: April 21, 2018).

From the interviews with the two informants above, it can be seen that the implementation of the traditional remote community (KAT) housing program in Pancoran Kum has been going well. However, there has not been a further program carried out by the Sula Islands Regency's regional government since the KAT housing program was established. Even though the local government of Sula District has promised the community that they will be fostered for three years, and the program carried out by the government so far has only created an enormous community dependency, not empowering the community. Programs that are designed and implemented sometimes do not educate and train the community to be independent in the future. The program implemented not to achieve people's welfare and independence but to pursue the target project following the specified time. In certain conditions, the institutional capacity must have been genuinely honed so that the community's sustainability continues to run even though external incentives have been stopped.

The programs run by the government so far have been more physical aspects such as housing construction, with the reason that the community can live permanently and easily accommodated so that the empowerment program can also run well. Later, the district government will propose other programs following the local community's conditions and local wisdom. On the other hand, an obstacle in guiding the KAT housing program is streamlining the social service and DSPMD so that priority programs for the social sector are often overlooked.

It is known from interviews conducted by researchers on the Head of KAT Mr. Rivai Masuku: At that time, the program was running well, but... it means now we are also inseparable from the political will. Yesterday at the end of 2015, the transition period between the old government and the new one, and we also need time to talk to the new government that we in this social program have something like this. Furthermore, yesterday we also regretted because suddenly, we were combined with relatively limited budgeting opportunities. This year in 2018, we only have 350,000,000 per year in two fields and three sections, so how do we want to run it? We have a program if our budget is only that. Indeed, the KAT housing program is from the State Budget, but the game rules must be funding often from the regions after the KAT housing program, so for this too, yes, we also cannot blame the local government. It is our responsibility to convince the local government. Frankly, after we were joined with PMD, we also had many programs that did not work. We also have many staff who complains because of budget limitations. We have many programs that do not touch the community; for example, this KAT program. "(Interview: May 5, 2018. At 12:10).

The political process that is accompanied by excessive interests send programs that are more touching to the community [33]. Further coaching after the KAT housing program could not be carried out because of the long transitional period of government and the impact of merging social services with PMD so that programs in the social sector are no longer included as priority programs. In this case, the Social Service and PMD should stand alone because, in a hierarchy, the Social Service has a Ministry of Social Affairs. The Community and Village Empowerment Office has a Ministry of Villages, each of which has special programs. It is not only the merging of these two offices that is an obstacle in the development of KAT housing, but the budget for the social sector is also limited in carrying out social programs. Indeed, the source of the KAT housing program budget is from the APBN, but there must be frequent funding from the local government after the KAT housing program.

While Mr. Taha (Head of the KAT Development Section) said: The source of the budget for this KAT program is from the State Budget, the de-concentration fund, and assistance task. Furthermore, according to the rules devolving de-concentration authority and assistance tasks to the local social service and district social service, the district program was taken over to implement it. We have to involve us from the provinces. Our task is to monitor and evaluate the central government program. Indeed, KAT development activities come from de-concentration, namely the State Budget. If the central government does not provide budgets for activities, the district must provide. Because at workshop time yesterday, the district government was also present to be able to allocate the activity budget through the APBD to several components of KAT empowerment activities, both at the preparation, 
empowerment, and after-development stages. For example, now, the central government has built a house through the cultural district like this. Roughly, what district would we like to do? So the region must have another contribution to the community ". (interview: May 19, 2018).

Based on the interview results, it can be said that the budget source for the KAT housing program from the State Budget is the de-concentration fund and co-administration tasks according to the rules. Devolution of de-concentration authority and co-administration task to the provincial and district social services. De-concentration funds for non-physical programs and assistance task funds for physical programs. KAT development activities are sourced from the APBN, but the regional government must also go through allocating development programs sourced from the APBD. There are some critical notes from the implementation of social empowerment to KAT that has been done. Local government support is the key to continuing the social empowerment of KAT at the advanced program stage. The coordination of various other development programs must have started since the beginning of the social empowerment process [34]. The Sula district's regional government's need for special attention towards Remote Indigenous Communities (KAT) because several fundamental reasons can influence the development process. As a citizen, KAT has the right to live prosperously, obtain essential social services, the right to participation in development, and protect from various disturbing conditions, both socially, culturally, economically, lawfully, and politically. The multiple rights held by KAT need to get attention and treatment from the government reasonably, as is the state's behavior in fulfilling citizens' rights in general. The regional government's attention to KAT is an implementation of the state's implementing citizens' welfare.

\subsection{Implementation of Remote Indigenous Community Housing Program}

The small indigenous community housing program is one of the programs carried out by the government to improve citizens' social welfare and provide livable housing for those in remote areas - the program-oriented increasing the people able to improve the quality of life and welfare of the community. The policy implementation of the small indigenous community housing program can run well if the communication process carried out by the Social Service and Village Community Empowerment can run effectively [35]. As a program, communication in socializing a plan is the first stage in preparing to implement remote indigenous communities' empowerment. One of the obstacles in implementing the KAT housing social empowerment program is replacing the service head, not following the rules and scientific basis. The service head as a leadership element does not know what will be communicated to his subordinates. Mr. Ali Umanahu, as the Head of DSPMD, said that: We have only been appointed as a Head of the DSPMD for 3 (three) months, so We also do not know what I will be communicating to my people regarding the program. Let alone to the subordinate, just to the regent, and We do not understand what will share related to social programs. We just heard the name. So this KAT housing program is good because this program is a landscape for the grassroots. We will ask to communicate this with the Special Head of Social Affairs in KAT, and related parties can guide the Pancoran Kum community in the coming year. (interview: May 7, 2018).

The substitution of the service head early greatly influences the agency's internal communication process to implement a program. Each newly appointed leader of service must need time to know the plans that will be run. In addition to Kadis's replacement that is too early, one of the other obstacles to carrying out coaching after the KAT housing program is merging the Social Service Office and the village community empowerment service. Pak Rivai Masuku, Head of KAT, said that: KAT housing initially went well since the Social Service was still standing alone in 2015. However, after the election, the social service has merged with the village community empowerment service, the post-KAT housing development program has not worked because of budget constraints. In this society, many ministry programs, one of which is the KAT housing program. We are from this social system if we arrive in Jakarta and want to lobby our social ministry program always to be ranked last because they prefer other regencies whose social services stand alone. We hope that social services in the district of Sula Islands can stand on their own. (Interview: May 6, 2018).

The merging of the Social Service and PMD is also one factor that inhibits communication in carrying out coaching after the KAT housing program. Communication is one of the crucial factors determining the successful implementation of public policy-communication activities to ensure whether the performance is under public policies' contents. One important function of communication is information through various communication forms such as face-to-face, socialization, oral or written reporting, dissemination of information using signage and signposts, and mass media communication. The dissemination of this information is essential to introduce and socialize the KAT housing program to the community. In implementing the social empowerment policy towards remote indigenous communities, in this case, the KAT housing program, several activities must be well informed, namely socialization. From the interview results, Mr. Rivai said that: The KAT housing program is a program sourced from the deconcentrated budget of the APBN. So, before this program was implemented, we from the district and provincial social services conducted an initial survey of activities' location. After determining the site, we also completed a program of socialization to the beneficiary community. (interview: May 6, 2018. 09.40).

KAT housing program is a program sourced from the APBN whose implementation stages are through site survey and program socialization. KAT housing communication program will run optimally if the relationship between the two parties goes well. Effective communication in organizations becomes essential, as does the organization's blood flow [36]. Miscommunication contributes equated with the destruction of the circulatory system in more than one organization. 
Communication becomes the most critical factor for organizations in getting information. Then with excellent communication, an organization will be able to run smoothly, and vice versa. Many organizational failures are caused by the organization's actors' lack of communication, coupled with cultural differences, respectively, that inhibits the communication process and leads to unfavorable effects, which is the absence of cooperation among administrators.

Based on the results of an interview with the Secretary of DSPMD Sula Islands Regency, Mr. Ahmad Banapon, regarding the communication of the KAT housing program to subordinates in the DSPMD agency: We here every program related to our field program always communicates among fellow, both fellow superiors and subordinates. Our communication aims to aim that every staff member who socializes a program understands the program's goals and objectives. Mr. Zaidun and Mr. Rivai always communicate this KAT housing program to the social staff. What will be conveyed to the community is easily understood by the people, and the community can receive it well. (interview: May 5, 2018. at 11:25).

Communication within the Social Service and Village Community Empowerment is a very complex and complicated process. Someone can hold it only for specific purposes or disseminate it. Besides, different sources of information will also give birth to different interpretations. For implementation to be effective, who is responsible for implementing a decision must know whether they can do it. The policy's performance must be accepted by all personnel and must clearly and accurately understand the KAT housing program's purpose and objectives. If the policymakers have seen the uncertainty of the actual policy specifications, they do not know what will be directed. The policy implementers are confused by what they will do so that if it is forced, it will not get optimal results. Insufficient communication with the implementers enormously influences policy implementation. Based on the results of interviews of some of the respondents above, it can be said that the head service substitution that is too early significantly affects the communication process within the internal agencies to implement a program.

Each newly appointed head of service must need time to know the programs that will be run. In addition to the Department Head's replacement that is too early, one of the other obstacles to implementing post-KAT housing development programs is merging the Office of Social Affairs and the Office of Community Empowerment. The KAT housing program is also a program sourced from the APBN whose implementation stages go through a location survey and socialization program process. Communication in the Social Service and Village Community Empowerment to superiors to subordinates went well. It is done so that the KAT housing program implementers can understand the KAT housing program's goals and objectives. Later, what is conveyed can be understood by the community. Program success is assessed from the extent of cooperation; in this case, communication and strengthening the implementer's activities are involved in implementing a program. With unified communication, all implementation mechanisms will be well coordinated.

\subsection{Resources for Remote Indigenous Community Housing Programs (KAT)}

Although the policy contents have been clearly and consistently communicated, the implementation will not run effectively due to lacks the resources to carry out. These resources can be in human resources, namely the implementer's competence and financial resources. Resources are essential factors for policy implementation to be effective. The policy's performance tends to be ineffective, even though the implementation instructions are transmitted (transmitted) carefully, clearly, and consistently if there is a lack of resources needed by the implementer to carry out the policy. The component of resources that can support the implementation of the system can be realized. The number of staff, the implementers' expertise, relevant and sufficient information to implement the policy and fulfillment and related resources in the program's implementation, the existence of authority that guarantees that the program can be directed as expected. There are supporting facilities that can be used to carry out activities such as funds and infrastructure. The resource factor has an essential role in the implementation of the KAT housing program. However, clarity and consistency of the rules set, and however accurate the delivery of program rules, if the policy implementers responsible for implementing policies lack resources, then implementing the procedures will run poorly. Mr. Rivai Masuku said that: We in society have quite good resources because they have been in this department for a long time, so they understand social programs more than We do. The small indigenous community housing program ran well to completion because of their help. They are field people who are ready to be deployed. The resources of the officers here are already poor sources of funds. (interview: May 6, 2018).

The condition for running an organization is ownership of resources. Resources in implementing policies play an essential role because policy implementation will not be valid if the supporting resources are not available. Based on the interview results above, the Social Service and Community Empowerment Village has useful resources in running the KAT housing program. However, the problem here is not about human resources but limited budget resources to guide remote indigenous communities. Of the various obstacles above, it is, of course, necessary to get the attention of the government. It should be considered to involve community organizations or non-governmental organizations actively and to utilize funding assistance from agencies and donor countries in a coordinated manner in handling KAT. Human resources from community institutions or non-government organizations in KAT empowerment will be more effective and efficient if the two parties work together side by side as equal partners.

The collaboration pattern between the Government and community institutions or non-government organizations in KAT empowerment can be shaped; First, partnership in KAT 
data collection. Second, indigenous peoples' assistance from the preparation stage to development and monitoring stages and evaluation. Third, mediator for resolving conflicts between local government and indigenous people/communities; and 4) provider of funds to implement activities outside government programs. The role and function of community institutions or non-governmental organizations help local governments carry out KAT empowerment activities whose population is increasing as new KAT are identified. In addition to community social workers who have been partners with local governments and community institutions or other non-governmental organizations, they can also collaborate with tertiary institutions. The role of tertiary institutions, especially those in the regions, will be more useful for the preparation phase (research, study, and identification of KAT) and program evaluation implementation.

\section{Conclusion}

The implementation of social empowerment programs for remote indigenous communities in the Kadai Tribe community in Pancoran Kum Hamlet, Waisakai Village, North Mangoli District, has been going well. According to the determined mechanism, and it is seen from the community positive response when receiving a remote customary community housing program that has been completed. The Remote Indigenous Community Empowerment housing program has been able to bring tribal residents to the condition of social welfare, from a woven bamboo house to a semi-permanent house, which is better than when the KAT housing program was not yet held. However, the post-KAT housing development program has not been implemented at all. It is feared that the community will no longer trust the government and reject the programs that will be implemented later.

The incorporation of the Social Service and Village Community Empowerment is an inhibiting factor in the implementation of social empowerment programs for remote indigenous communities in the Kadai Tribe community in Pancoram Kum Hamlet, Waisakai Village, Mangoli Utara Timur District. Limited funds are an inhibiting factor in implementing social empowerment programs for remote indigenous communities in the Kadai Tribe community in Pancoram Kum Hamlet, Waisakai Village, North Mangoli District. Every year is only IDR 350 Million budgeted in the social sector, one of which is in KAT Midwives.

Sula District Government and Social Service and Community Empowerment Village to be able to support better the social empowerment program of remote indigenous communities to be better materially. They improved the quality of empowerment and cooperation among all to achieve community welfare, social empowerment programs for small indigenous communities. The Government of Sula District, Regent, and DPRD separate the Social Service and Village Community Empowerment to realize the successful implementation of social empowerment programs for remote indigenous communities in the Sula Islands District.

The Government of the Sula Islands Regency can provide maximum action against the obstacles that occur in implementing the Social Empowerment program for remote indigenous communities in the Sula Islands Regency. There needs to increase funding portion of both the central and regional governments. The implementation of the empowerment of remote indigenous communities is not impressed as it is because members of remote indigenous communities also have the same rights in meeting their needs. The Provincial Government needs to build cooperation with the Regency / City Government to follow up on the Central Government's empowerment program after the community has been successfully relocated or organized in one settlement.

\section{Acknowledgements}

We appreciate the Sula District government, all remote indigenous communities of Pancoran Kum village, and all those who have helped in this study completion. Besides, our gratitude and appreciation to the Rector of Universitas Muhammadiyah Maluku Utara support and attention in this study. Appreciation was also conveyed for the corrections and suggestions to those who have reviewed this paper.

\section{References}

[1] T. Mardikanto and P. Soebianto, Community Empowerment in a Public Policy Perspective, Indonesian. Bandung: CV. Alfabeta, 2012.

[2] H. A. Nikkhah and M. Redzuan, "Participation as a medium of empowerment in community development," Eur. J. Soc. Sci., vol. 11 , no. 1 , pp. 170-176, 2009.

[3] S. H. Appelbaum, D. Hébert, and S. Leroux, "Empowerment: Power, culture and leadership - a strategy or fad for the millennium?," J. Work. Learn., vol. 11, no. 7, pp. 233-254, 1999.

[4] G. K. Sutawa, "Issues on Bali Tourism Development and Community Empowerment to Support Sustainable Tourism Development," Procedia Econ. Financ., vol. 4, no. Icsmed, pp. 413-422, 2012.

[5] Y. F. Setyobudi, "Pengentasan Kemiskinan Melalui Program Nasional Pemberdayaan Masyarakat (PNPM) Mandiri," Dimensi, vol. 1, no. 3, pp. 176-189, 2012.

[6] F. Merlan, From a Comparative Perspective: Epilogue, vol. 7. 2017.

[7] S. Soemantri, Anthology of Indonesian Constitutional Law, Indonesia. Bandung: Alumni, 1992.

[8] H. K. Klein and D. L. Kleinman, "The social construction of technology: Structural considerations," Sci. Technol. Hum. Values, vol. 27, no. 1, pp. 28-52, 2002.

[9] J. A. Kuypers, Rhetorical criticism: Perspectives in action. Lexington: Lexington Books, 2009.

[10] E. Mayer, RR, Greenwood, The design of social policy. Prentice-Hall, 1980. 
[11] D. L. Weimer and A. R. Vining, Policy Analysis. Taylor \& Francis, 2017.

[12] H. D. Lasswell and K. Abraham, Power and society: $A$ framework for political inquiry. Transaction Publishers, 2013.

[13] Thomas R. Dye, Understanding Public Policy, 9th ed. New York: Prentice Hall, 1998.

[14] H. Eulau and P. Kenneth, Labyrinths of democracy: Adaptations, linkages, representation, and policies in urban politics. Ardent Media, 1973.

[15] C. J. Friedrich, "Public policy and the nature of administrative responsibility," Public, pp. 3-24, 1940.

[16] J. E. Anderson, D. W. Brady, C. S. Bullock, and J. Stewart, Public policy and politics in America. North Scituate, MA: Duxbury Press, 1978.

[17] D. Easton, "The perception of authority and political change," Authority, vol. 179, 1958.

[18] P. Bridgman and D. Glyn, The Australian policy handbook. Allen \& Unwin, 2004.

[19] G. H. Jenkins, The foundations of modern Wales: Wales 1642-1780. USA: Oxford University Press, 1987.

[20] E. Bardach, The Implementation Game. Massachusette: Cambridge, 1991.

[21] George C. Edwards III, "Presidential Legislative Skills as a Source of Influence in Congress," Pres. Stud. Q., vol. 10, no. 2, pp. 211-223, 1980.

[22] Van Horn, Carl E. and Donald S. Van Meter, "The implementation of intergovernmental policy," Policy Stud. Rev. Аnпu., vol. 1, no. 1, pp. 97-120., 1977.

[23] S. Paul and D. Mazmanian, "The Conditions of Effective Implementation: A Guide to Accomplishing Policy Objectives," Policy Anal., vol. 5, no. 481-504, 1979.

[24] R. J. Parsons, "Empowerment practice," Encycl. Soc. Work, 2013.

[25] D. Gagliardi, L. Schina, M. L. Sarcinella, G. Mangialardi, F. Niglia, and A. Corallo, "Information and communication technologies and public participation: interactive maps and value added for citizens," Gov. Inf. Q., vol. 34, no. 1, pp. 153 $166,2017$.

[26] M. S. Reed, "Stakeholder participation for environmental management: A literature review," Biol. Conserv., vol. 141, no. 10, pp. 2417-2431, 2008.

[27] P. S. Jones, "Urban regeneration's poisoned chalice: Is there an impasse in (community) participation-based policy?," Urban Stud., vol. 40, no. 3, pp. 581-601, 2003.

[28] K. Hung, E. Sirakaya-Turk, and L. J. Ingram, "Testing the Efficacy of an Integrative Model for Community Participation," J. Travel Res., vol. 50, no. 3, pp. 276-288, 2011.

[29] J. M. Cohen and N. T. Uphoff, "Participation's place in rural development: Seeking clarity through specificity," World Dev., vol. 8, no. 3, pp. 213-235, 1980.

[30] C. Van Vollenhoven, "Law Areas," in Het Adatrecht van Nederlandsch-Indie (Van Vollehhoven on Indonesian Adat Law), Netherlands: The Hague-Martinus Nijhoff, 1981.

[31] H. B. Teer, Adat Law In Indonesia. Jakarta: Bhratara, 1962.

[32] Miles, M. B. and A. M. Huberman, Qualitative data analysis: An expanded sourcebook. Sage publications, 1994.

[33] Ibrahim, Abdul Halil Hi, Muhlis Hafel, and Abdul Rahman Abdullah, "The Implementation Of Policy On Expansion Development of Employment Opportunities For Productive Workforce In Tidore City," International Journal of Scientific \& Technology Research, vol. 7, no. 8, pp. 269-275, 2018.

[34] Ibrahim, Abdul Halil Hi, Aji Deni, and Ramli Sugianto. "The Performance of Local Government Company In Tidore City," International Journal of Scientific \& Technology Research, vol. 7, no. 12, pp. 211-215, 2018.

[35] Ibrahim, Abdul Halil Hi, Abdullah Kaunar, and Ichsan Nurfalah Adrias, "Government Performance on Property Tax Services Of Rural And Urban Areas In Ternate City," International Journal of Scientific \& Technology Research, vol. 7, no. 9, pp. 161-166, 2018.

[36] Ibrahim, Abdul Halil Hi, Muhlis Hafel, and Iryani S. Lamasi, "Jailolo Bay Festival As A Model For Developing Cultural Tourism In West Halmahera," International Journal of Scientific \& Technology Research, vol. 7, no. 9, pp. 167-176, 2018. 